\title{
COMO PROTEgER A CRIANÇA DE 0 A 24 MESES CONTRA A INFECÇÃO *
}

\author{
* * Miriam Susete de O. Rosa \\ * * Anne Marie Helene de Richter \\ * * Rossana Rosa Bercini
}

\begin{tabular}{l|l} 
& RBEn/06 \\
\hline $\begin{array}{l}\text { ROSA, M.S.O. e colaboradoras - Como proteger a criança de } 0 \text { a } 24 \text { meses contra a } \\
\text { infecção. Rev. Bras. Enf.; DF. } 32: 271-295,1979 .\end{array}$ \\
\hline
\end{tabular}

\section{INTRADUÇÁO}

A população infantil, de zero a quatorze anos, tem sidc nos últimos tempos objeto de atenção das autoridades governamentais, pois este grupo representa quantitativamente $41,20 \%$ da população total do país e, qualitativamente, a de condições mais vulneráveis a acidentes mórbidos.

As a.ltas cifras de morbidade e mortalidade infantil por causas evitáveis, associadas à alimentação deficiente e às más condições de saneamento, fazem com que haja uma preocupação efetiva do governo com esta população.

A constatação desta realidade e observações assistemáticas durante o estágio hospitalar, onde ressaltou-se o problema de infecção como causa de internação, motivou o grupe de estudantes da disciplina de Enfermagem Pediátrica da
Escola de Enfermagem da Universidade Federal do Rio Grande áo Sul, a questionar os fatores predisponentes do processo infeccioso.

Baseado em informações colhidas em revisão da literatura e entrevistas com equipe multiprofissional, foi elaborado um estudo prévio com a finalidade de se identificar: faixa etária mais atingida, freqüência de infecções e fatores que poderiam estar contribuindo para esta ocorrência. Este estudo foi realizaāo no Hospital da Criança Santo Antônio, estabelecimento escolhido por ser de exclusivo atendimento pediátrico e proporcionar assistência a crianças de todo o Estado do Rio Grande do Sul.

Para o alcance dos objetivos a que se propunha este estudo, foram coletadas informações de cento e setenta e dois prontuários dos cento e oitenta e cinco existentes na ocasião.

* Trabalho elaborado por alunos do Curso de Graduação e Enfermagem da UFRGS, sob a orientação da Prof.a Marina Pizzato da mesma Universidade.

Mereceu o Prêmio Marina de Andrade Resende - RJ. - 1979. 
ROSA, M.S.O. e colaboradoras - Como proteger a criança de 0 a 24 meses contra a infeç̧ão. Rev. Bras. Enf.; DF. 32 : 271-295, 1979.

Após a tabulação dos resultados, delimitou-se a alta freqüência de infecçōes na população $(\mathbf{7 6 , 7 4 \%})$, onde $\mathbf{7 9 , 4 0 \%}$ pertenciam à faixa etária de zero a vinte e quatro meses.

Estes enfoques e as colocaçōes de Laurenti em conferência sobre a "Situaçāo da Criança no Brasil - Indicadores médico-sociais: sua análise e influência na saúde da criança", proferida em maio de 1979, em São Paulo, onde é destacado como indicadores de saúde: a taxa de mortalidade; vida média da população; freqüência de doenças infecciosas; rede de água e esgoto; número de médicos e enfermeiros por habitante e coeficientes de mortalidade infantil; forneceu subsídios para a abordagem do estudo e formulação do instrumento.

Frente ao exposto questiona-se:

1. Quais os fatores que estariam contribulndo para a ocorrência do processo infeccioso?

2. Quais as açōes de enfermagem t’m níveis de prevenção primária fara limitar ou eliminai estes fatores?

\section{QUADRO DE REFERENCIA BIBLIOGRAFICA}

Neste momento, faz-se presente citar alguns fatores que, acredita-se influem na ocorrência de infecçōes. Dentre eles, pareceu mais importante salientar as aspectos que se referem à imunidade, à vacinação, ao aleitamento materno, à nutrição, às condiçōes básicas de higiene corporal e embiental.

\section{1 - Imunldade}

Dos fatores já citaỏos, passa-se a desenvolver os relativos à imunidade. Esta é definida por CARELLI (1972), como sendo os meios que o homem possui para lutar contra as infecçōes, resis- tindo-as ou vencendo-as. E ainda descrita como condiçāo que o indivíduo tem de resistir a quase todos organismos que tendem a invadir ou lesar seus órgãos ou tecidos. (GUYTON, 1977)

A imunidade é classificada em duas categorias: inata e adquirida ou adaptativa.

No caso da imunidade inata não é necessária prévia exposição ao agente invasor, o indivíduo nasce com ela, sendo constituída por processos gerais como fagocitose, resistência da pele, ação das secreçōes ácidas do estômago e a presença de alguns processos químicos no sangue que destroem ou fixam organismos estranhos ou toxinas.

A imunidade adquirida ou adaptativa depende de um sistema imune especial que produz anticorpos e linfóticos sensibilizados quando da presença de antígenos específicos. Podem ser formadas tanto ativa, quando o próprio indivíduo sintetiza os anticorpos, como passivamente, quando recebe os anticorpos já formados em outro indivíduo ou em animal.

$\mathrm{Na}$ imunidade adquirida cabe salientar seus dois tipos básicos: a linfocitária, que é aquela em que ocorre a formação de grande número de linfócitos especializados para agir contra agentes estranhos e a humoral que é aquela em que o organismos desenvolve anticorpos circulantes denominados imunoglobulinas.

São cinco as imunoglobulinas conhecidas: imunoglobulina G (IgG), imunoglobulina $\mathbf{M}$ (IgM), imunoglobulina $\mathbf{A}$ (IgA), imunoglobulina D (IgD) e a imunoglobulina $E$ (IgE).

A lgG distribui-se pelos espaços intra e extra-vasculares, apresenta baixo peso molecular, atravessa facilmente a barreira transplacentária e sua concentração parece estar ligada ao período gestacional, sendo grandemente responsável pela produção de anticorpos no recém-nascido (RN). (CARELLI, 1072; WAECHTER e col., 1979) 
ROSA, M.S.O. e colaboradoras - Como proteger a criança de 0 a 24 meses contra a infeçāo. Rev. Bras. Enf.; DF. 32 : 271-295, 1979.

O feto poderá produzi-la a partir da décima terceira semana da gestação. (ALFORD 1971 appud FREITAS 1974)

Os valores desta imunoglobulina em RN podem estar iguais ou superiores aos valores encontrados da mãe. (BELLANTI \& ARTENSTEIN 1964 appud FREITAS 1974)

Esta imunoglobulina tem uma média de vida de vinte a trinta dias e sua concentração no soro cai durante os primeiros meses, atingindo valores baixos entre o segundo e o quarto mês, chegando o seu valor a zero por volta do quinto mês. O RN passa a sintetizar a IgG, mais significativamente, com a queda da IgG materna, atingindo níveis do adulto entre os cinco e os seis anos, sendo sua ação essencial sobre bactérias grampositivas, vírus, parasitas e fungos. (FREITAS, 1974; AVERY, 1978)

Quanto ao que se refere à IgM, sabese que ela é encontrada, principalmente, no interior dos vasos, sendo sintetizada essencialmente no baço e sendo seu peso molecular elevado o responsável pela resposta inicial ao antígeno. Não atravessa a barreira placentária, podendo o feto sintetizá-la a partir ca vigésima semana gestacional. (CARELLI, 1972)

Esta imunoglobulina é considerada responsável pela aglutinação de antígenos específicos como as bactérias gramnegativas e células vermelhas, fixando o complemento com eficiência. (FREITAS, 1974; AVERY, 1978)

Os valores normais desta imunoglobulina são de vinte $\mathrm{mg}$ e sua elevação no RN durante a primeira semana de vida sugere diagnóstico de infecção intra-uterina. O RN sintetiza intensamente esta imunoglobulina, atingindo níveis do adulto por volta de um ano de idade. (FREITAS, 1974, AVERY, 1978)

A IgA é encontrada, essencialmente, nas secreçōes e é proảuzida, provavelmente, pelas células plasmáticas e grandes linfócitos. (CARELLI, 1972)

Ela parece estar muito relacionada com a proteção da mucosa respiratória e do trato gastrointestinal e, sua presença no sangue do RN, em níveis elevados poderá indicar severa infecção intrauterina, porque ela, normalmente, aparece no sangue da criança, aproximadamente, com um mês de vida, chegando aos níveis do adulto por volta da adolescência. (CARELLI, 1972; BLANKENSHIP, 1969 appud FREITAS 1974; WAECHTER e col., 1979)

No que se refere à IgE, estaria ligada a mastócitos e ser responsável pela maioria das reações alérgicas, enquanto que a IgD é de importância desconhecida, sendo encontrada em doses muito pequenas no soro. (WAECHTER e col., 1979)

AVERY (1978), sugere que os anticorpos herdados passivamente, além de desempenhar a função de proteção ao $\mathrm{RN}$, também podem interferir com a síntese ativa de anticorpos estimulados por imunização. Refere ainda estudos em que se constatou a interferência e ncutralização dos vírus vacinais, modificando a formação dos anticorpos específ1cos. Indica que a vacinação por germes mortos, na ldade de dois a três meses, parece não ser afetada pela imuntdade passiva, enquanto que a vacinaçäo por virus vivos deveria ser retirada ate o fim do primeiro ano, pelo inibitório presente na sintese destes anticorpos.

GUYTON (1977) considera que embora haja um decréscimo dos níveis de gamaglobulinas logo após o nascimento, estes ainda protegem a criança até quase os seis meses contra infecçōes como difteria, sarampo, poliomielite e variola, contestando o hábito da vacinaęão, antes deste período e que os anticorpos herdados contra a coqueluche, normalmente, são insuficientes, alertando para a necessidade da vacinação no primeiro mês de vida.

A hipogamaglobulinemia transitória da infância é refletida como causa de grande importância em pediatria, pois uma deficiência do sistema humoral da criança provoca um atraso da produção 
ROSA, M.S.O. e colaboradoras - Como proteger a criança de 0 a 24 meses contra a infecçāo. Rev. Bras. Enf.; DF. 32 : 271-295, 1979.

de suas próprias imunoglobulinas, deixando-a mais suscetivel as infecções. Este atraso poderá ser de semanas ou até de um ano, fazendo com que as infecções nestas crianças sejam tão graves, quanto nas hipogamaglobulinemias verdadeiràs. Sua ocorrência poderá ser por incompatibilidade entre as imun'). globulina $G$ maternas e as fetais. (JOBIM, 1972)

O sexo da criança também tem sido consideraclo cumo uma condição predisponente na infecção do $\mathrm{KN}$, devido aos fatores que regulam a sintese de imu: $\left.\}_{1}\right)-$ globulinas astarem no cromossoma $\mathrm{X}$.

Sugere-se que, talvez, a presença de dois cromossomas $\mathrm{X}$ possa conferir maior diversificação genética par’ $\mathfrak{i}$ as defesas femininas entretanto, não há nada confirmado. (AVERY, 1978)

A partir do exposto, conclui-se que o RN \& o infante estão mais vredispostos à infecção devido à sua imaturidade imunitária, principalmente, acentuada nos prematuros.

A pele do RN é fina e vulnerável a traumatismos, facilitando a penetração de germes.

O coto umbilical serve conio porta de entrada para microorganismos.

O RN hercla passivamente certa imunidade de sua mãe, não podenclo, entretanto, sintetizar seus próprios anticorpos em níveis significativos e, tendo decréscimo acentuado até o primeiro mês de vida, tornando-se mais suscetivel às infecções.

A imunização ativa dura longo tempo e, para que a criança forme seus próprios anticorpos, torna-se necessário que ela se infecte ou receba uma vacina contendo agentes etiológicos ou seus produtos na forma inócua. (COCKBURN, 1977)

\section{2 - Vacinação}

A imunização vacinal é o meio profilático mais eficaz e de aplicação mais rápida de que as autoridades ce saúde pública dispõem para o controle de doenças transmissíveis. Seu uso ainda é reduzido, especialmente, nas áreas onde se faz mais necessário. (BASTOS, 1976; MORLEY, 1977)

A vacinação é necessária a todos os individuos suscetíveis, de todas as idades, especialmente, em crianças até a idacle escolar. E significativo seu baixo custo em termos médicos, econômicos e sociais, comparando-se com os custos da enfermidade em si e seu tratamento. (VERONESE, 1972 appud BASTOS, 1976)

Conforme publica ção OPS/OMS (1978) as vacinas situam-se em duas categorias: vacinas com antígenos mortos e vacinas com antígenos vivos. As vacinas com antígenos mortos, chamados inativadas, são preparadas com o agente etiológico morto ou com produtos tóxicos transformados em substâncias inoferısivas chamadas toxóides, devendo ser administradas con o mínimo de duas doses para oferecer imunidade suficiente e com doses de reforço para reativar esta imunidade. As vacinas com antígenos vivos, embora atenuados, têm ação mais prolongada e são preparadas com agentes etiológicos modificados, tornando-os inócuos porém capazes de infectar o organismo, estimulando-o a produzir anticorpos específicos. Esta vacina pode causar uma infecçảo leve no organismo receptor e uma dose parece ser suficiente para conferir imunidade.

BLANCK et alli (1976) \& VERONESE (1978) constatam que, atualmente, existe imunização contra as seguintes enfermidades: tuberculose, poliomielite, difteria, tétano, sarampo, variola, caxumba, coqueluche e outras de menos vulto.

Quanto à tuberculose, é considerada ainda uma importante causa de morbidade e mortalidade em todas as faixas etárias, sendo difunōida e agravada em regiōes de baixo nível sócio-econômico, 
ROSA, M.S.O. e colaboradoras - Como proteger a criança de 0 a 24 meses contra a infecçäo. Rev. Bras. Enı.; DF. 32 : 271-295, 1979.

de maiores contatos inter-humanos com doentes bacilíferos e de reduzida imunização protetora pelo BCG. O indivíduo vacinado expõe-se ao impacto de uma primo-infecçāo artificial benigna, tornando-se praticamente isento do risco de adquirir a infecção primária por germes virulentos.

A centralização vacinal em jovens com menos de quinze anos de idade acontece por ser a população brasileira constituída de $53 \%$ de jovens com menos de quinze anos; devido a isso, o M1nistério de Saúde do Brasil, em 1976, declarou obrigatória a vacinação pelo $\mathrm{BCG}$ ID, em todo o Território Nacional, em crianças desta faixa etária, sem realização de teste tuberculínico prévio. A vacinação pode ser feita nos primeiros meses de vida, principalmente, em populaçôes de maior risco, atendendo a critérios epidemiológicos regionais.

No Brasil, atualmente, há diversos comportamentos nas diferentes regiōes fisiográficas, relativos à difusão da infecção tuberculosa, sendo que os índices de prevalência desta infecção estão acima de $10 \%$ aos quatorze anos, mesmo nas regiōes de mais baixa endemicidade.

(BRÓLIO, 1977)

NASCIMENTO \& LIMA 1976 appudd BRÓLIO 1977 relata que a Divisão Nacional de Tuberculose (DNT) revelou que a prevalência da infecção tuberculosa em crianças na idade de ingresso escolar, dos seis aos nove anos, no período de 1970 a 1973, foi a seguinte:

Regiāo Norte $\ldots \ldots \ldots \ldots \ldots \ldots \quad 16,9 \%$

Região Nordeste $\ldots \ldots \ldots \ldots \ldots \ldots, 14,2 \%$

Regiāo Sudeste $\ldots \ldots \ldots \ldots \ldots \ldots \quad \mathbf{8 , 3 \%}$

Região Sul $\ldots \ldots \ldots \ldots \ldots \ldots \ldots, \quad 6,7 \%$

Regiāo Centro-Oeste ........ $\quad \mathbf{7 , 9 \%}$

Média das Regiōes . . . . . . . . 13,8\%

Fonte: BRólIO (1977) pág. 425.
Os autores citados afirmam que houve um decréscimo anual de $2,6 \%$ de crianças, dos seis aos nove anos, infectadas. Este elevado risco demonstra a amplitude do problema brasileiro, comprovando o alto índice de eliminadores de bacilos tuberculínicos na população, tornando mais urgente a profilaxia vacinal em massa pelo BCG ID.

O Rio Grande do Sul, atualmente, utiliza a vacinação pelo BCG $\mathrm{ID}$, em crianças na idade escolar.

Nos paises em desenvolvimento, a poliomielite é causa freqüente de severas paralisias, sendo que a maioria das crianças afetadas têm poucas possibilidades de sobreviver e chegar à idade adulta. (MORLEY, 1977)

AMATO NETO (1971) relata a existência comprovada de tipos imunológicos diferentes do vírus: tipo I (Brunhilde), tipo II (Lauring) e tipo III (Leon), ressaltando a necessidade de pesquisar uma vacina anti-pólio orientada para uma trivalência, atingindo os três tipos virais. A vacina do tipo Sabin, produzida com vírus vivos atenuados, é trivalente, administrada via oral, possuindo características aproximadas ao vírus ideal. A imunidade efetiva é estabelecida através de altos niveis de anticorpos séricos, pela multiplicação do $v$ rus vacinal no intestino, por um período mais ou menos longo, sendo encontrado nas fezes a partir de vinte e quatro a quarenta e oito horas, perdurando de trinta a cinqüenta dias. Os anticorpos sangüíneos, que protegem contra a infecção poliomielítica, já devem ser encontrados na circulação uma semana após a vacinação. Um intervalo de qua. tro a seis semanas entre as vacinaçōes é suficiente par'a desenvolver a multipllcação dos vírus da dose anterior, ou de vírus patogênicos que, por ventura, estivessem interferindo sobre o resultado da vacinaçao. Intervalos superiores a dois meses expõem a criança, caso trä 
ROSA, M.S.O. e colaboradoras - Como proteger a criança de 0 a 24 meses contra a infecção. Rev. Bras. Enf.; DF. 32 : 271-295, 1979.

tiver sido prisduzida a imunidade suficiente com a dose anterior. No RN dá-se a multiplicaçāo viral, mas não é desenrolvida uma reação imunitária eỉiciente c'evido à imaturidade áo sistema imunitárió e à interferência dos anticorpes maternos.

O uso da vacina Sabin, em três doses, determina $100 \%$ de imunidade para os vírus poliomielíticos tipos I e II e 97\% para o tipo III, atingindo uma eficácia entre $90 \%$ e $97 \%$.

A maior incidência da joliomielite ocorre entre os seis meses e os três anos de idade $(95 \%)$, confirmando a preferência de se iniciar a vacinação aos aois meses, de modo que a criança aos seis meses já tenha recebido as três primeiras doses. $O$ reforço é feito após um ano da terceira dose, com a finalidade de aumentar o teor de anticorpos. (BLANCK et alii, 1976; AMATO NETO, 1971)

A Imunização da difteria, soqueluche e tétano é realizada através da vacina tríplice DPT. Devido a isto, estas serão analisadas concomitantemente. (AMATO NETO, 1971; BLANCK et ali1, 1976)

Com relação à difteria, esta é consideraáa como grande causa de mortalidade infantil, quando não tratada ou atendida tardiamente. Ao contrário de outras doenças, é mais grave nos locais onde há vida urbana. Atualmente, é alarmante o número crescente de casos diftéricos em adultos, devido a não aplicação ơas doses de reforço na época oportuna, pois como afirma AMATO NETO (1971), se $70 \%$ da população, da faixa de um a quinze anos, fosse imunizada contra difteria esta, praticamente, poderia ser erracicada, pois a imunidade oferecida pela vacina é duradoura.

A coqueluche é uma importante causa de morbidade e mortalidade entre as doenças infecciosas nos países em desenvolvimento. altamente severa, de modo especial, em crianças com menos de um ano de idade, causando mais de um terço de óbitos, se adquirida antes dos cinco meses de idade. A criança, geralmente, morre com pneumonia ou hemorragia cerebral.

A eficácia da vacina anti-coqueluche é menos se a compararmos com a do tétano e da difteria, pois sua resposta imunitária é deficiente e causa reaçōes indesejáveis e mais graves. Deve, contudo, incluir todos os tipos de Bordetelas conhecidos, com a finalidade de evitar que determinados vírus, não atingidos pela imunização, se desenvolvam através da seleção.

Quanto ao tétano. constitui-se numa doença encontrada freqüentemente em países desenvolvidos, devido a um allmento dos acidentes de trânsito ou outros ferimentos ao ar livre.

Uma variedade especial e, particularmente severa, é encontrada em RN cujo cordão umbilical não foi cortado assepticaniente. Nesses casos, observase uma alta mortalidade pois, cerca de três quartos de crianças afetadas, morrem. Previne-se este tipo de tétano através de técnicas assépticas no corte do cordão umbilical e pela imunização da gestante, pois seus anticorpos serão transmitióos ao feto através da placenta.

Tem sido demonstrada amplamente que uma imunização básica adequada e com reforços a intervalos regulares fornece uma satisfatória proteção relativa ac tétano, pois na resposta imunitária apresenta níveis sorológicos protetcres, com duração proslongacia.

A vacina tripliee, DPT, é administrada em três duses, iniciando-se ans dois meses de idade, ccm intervalos de dois meses entre cada ciose. $O$ primeiro reforço é āado um ano apis a aplicaçāo da terceira dose e o segundo após um ano e meio do primeiro. iAMATO NETO, 1971; BLANCK et alii, 1976; MORLEY, 1977) 
ROSA, M.S.O. e colaboradoras - Como proteger a criança de 0 a 24 meses contra a infecçāo. Rev. Bras. En?.; DF. 32 : 271-295, 1979.

O sarampo é de origem viral e endêmico em todas as regiōes do mundo, sendo considerado, atualmente, como a infecção causadora do maior indice de mortalidade, especialmente, quando associado à desnutrição. Este quadro é agravado, por ser sua incidência, prevalentemente, em crianças de cinco meses a três anos de idade. A maioria dos óbitos ocorre devido à pneumonia, diarréia ou inflamação cerebral que são complicações do sarampo. (AMATO NETO, 1971; MORLEY, 1977)

A vacinação com vírus vivos atenuados induz uma soro-conversão entre $90 \%$ e $100 \%$ das crianças suscetíveis, atingindo nível máximo em torno do trigésimo dia após a inoculação, reduzindo-se no quarto ou quinto ano. Como o sarampo é muito severo antes do primeiro ano de vida e sua incidência é muito elevada no Brasil, a vacinação é realizada em torno do oitavo mês pois após o sexto mês os anticorpos maternos são inexistentes. Porém, as crianças que a recebem entre o oitavo e o décimo segundo mês correm o risco de $15 \%$ não adquirirem imunidade. Aconselhase, então, a aplicação de uma dose de reforço aos doze meses. Nos ambientes ou épocas do ano em que a moléstia não é tão freqüente, administra-se apenas uma dose no primeiro ano de idade. (AMATO NETO, 1971; BLANCK et alii, 1976)

Com relação à variola, em janeiro de 1977, a Organização Mundial de Saúde, decalrou-a erradicada no mundo, pois considerou-se eliminado o último reduto da moléstia, situado na Etiópia. (HENDERSON, 1977)

A poucos dias, porém, foi noticiado o reaparecimento da varíola no Quênia. Percebe-se uma controvérsia relativa a este assunto, pois não se sabe até que ponto a doença está sob controle, devido à vacinação em massa. No entanto, várlos países, inclusive o Brasil, pensam em eliminar a vacinação anti-varioólica, o que poderá favorecer o reaparecimento da doença. (AMATO NETO, 1979)

O emprego de vacina de boa potência, com técnica adequada, produz imunização extremamente eficaz, promovendo soro-conversão aproximada de $100 \%$.

A pequena ou nula incidência, em nosso país, determina a primo-vacinação após o primeiro ano e doses de reforço de três em três anos. (AMATO NETO, 1971; BANCK et alii, 1976)

A caxumba atinge todas as faixas etárias, especialmente crianças em idade escolar. Tem evolução benigna, porém são consideráveis suas complicações severas desenvolvidas nas gônadas masculinas, levando muitas vezes à esterilidade.

Sabe-se que crianças, que tenham sido imunizadas com uma dose de vacina, apresentam respostas em níveis protetores em $97 \%$ dos casos. Devem ser vacinadas crianças com mais de um ano de idade pois, anteriormente, não são suscetíveis, especialmente, visando as crianças em idade pré-púbere. (AMATO NETO, 1971)

Quanto à rubéola, é uma doença benigna, sendo que o interesse na profilaxia vacinal não está relacionado com o seu quadro, quase assintomático, mas com a rubéola congênita. Se a mãe adquire a doença nas primeiras dezesseis semanas da gravidez, o feto fica sujeito a nascer com malformações quando não ocorre morte fetal, resultando em aborto.

Nas primeiras quatro semanas de gestação, o índice atingido chega a $80 \%$, caindo para $30 \%$ ou $40 \%$ no segundo mês e para $20 \%$ a $10 \%$ no terceiro ou quarto mês de gravidez.

Existem vários tipos de vacinas, dando origem a elevada conversão sorológica, variando entre $95 \%$ a $100 \%$.

A preferência vacinal é em crianças de idade escolar, por ser a maior fonte de disseminação viral na comunidade. (AMATO NETO, 1971; BANCK et alih, 1976) 
ROSA, M.S.O. e colaboradoras - Como proteger a criança de 0 a 24 meses contra a infecção. Rev. Bras. Enf.; DF. 32 : 271-295, 1979.

Esquema vacinal sugerido pelo Ministério de Saúde do Brasil:

FAIXA ETARIA

VACINA

VIA DE ADMINISTRAÇÃO

\begin{tabular}{|c|c|c|}
\hline 2 meses & $\begin{array}{l}\text { BCG } \\
\text { DPT (tríplice) } \\
\text { Anti-pólio (SABIN) }\end{array}$ & $\frac{\text { DI }}{\text { ORAL }}$ \\
\hline 4 meses & $\begin{array}{l}\text { DPT } \\
\text { SABIN }\end{array}$ & $\begin{array}{c}\text { IM } \\
\text { ORAL }\end{array}$ \\
\hline 6 meses & $\begin{array}{l}\text { DPT } \\
\text { SABIN }\end{array}$ & $\begin{array}{c}\text { IM } \\
\text { ORAL }\end{array}$ \\
\hline entre 6 e 8 meses & ANTI-SARAMPO & $\mathbf{I M}$ \\
\hline 12 meses & ANTI-VARfOLA & PRESSAO MƯLTIPLA \\
\hline Até 1 ano & $\begin{array}{l}\text { ANTI-SARAMPO (ref.) } \\
\text { ANTI-CAXUMBA } \\
\text { ANTI-RUBEOLA }\end{array}$ & $\begin{array}{l}\mathbf{I M} \\
\mathbf{I M} \\
\mathbf{I M}\end{array}$ \\
\hline 18 meses & $\begin{array}{l}\text { DPT (reforço) } \\
\text { SABIN (reforço) }\end{array}$ & $\underset{\text { ORAL }}{\text { IM }}$ \\
\hline 36 meses & $\begin{array}{l}\text { DPT (reforço) } \\
\text { SABIN (reforço) }\end{array}$ & $\underset{\text { ORAL }}{\text { IM }}$ \\
\hline
\end{tabular}

\section{3 - Nutrição}

Atualmente, tem sido enfatizada a importância do estado nutricional na infância como uma das causas que influenciariam na instalação e agravamento dos processos infecciosos

Considera-se nutrição o processo orgânico de metabolizar em células e humores os alimentos ingeridos, com a finalidade de manter o organismo vivo e sadio.

Os alimentos são formados de nutrientes: proteinas, gorduras, hidratos de carbono, vitaminas, sais minerais e água, que são substâncias crom funçōes biológicas específicas. (COUTINHO, 1966; MARCONDES, 1970; GUYTON, 1976)
Para que a criança seja considerada bem nutrida, cu seja eutrófica, é preciso que tenha um aumento ponderal regular e progressivo dentro dos limites isisiológicos, o que é conseqüente a uma ingesta adequada de alimentos. (PERNETTA, 1954)

Por apresentar um metabolismo mais dinâmico que o adulto, a criança pode, facilmente sofrer distúrbios nutritivos. Estes são devidos ao seu crescimento acelerado, menor suporte a desvios e erros alimentares, além da interdependência entre psiquismo e alimentação.

Os distúrbios podem ocorrer pela de. fíciência de assimilação dos alimentos pelo organismo, podendo gerar um desequilíbrio orgânico: as distrofias e os 
ROSA, M.S.O. e colaboradoras - Como proteger a criança de 0 a 24 meses contra a infecçāo. Rev. Bras. Enf.; DF. 32 : 271-295, 1979.

psíquicos, o retardo mental, predispondo a ação de microorganismos patogênicos. (JAMES, 1946 appudd MARCONDES, 1970; SALUM, 1976)

Nas distrofias ou m:l nutrição, subnutrição e desnutrição, a curva ponderal é irregular com aumento lento, estacionando ou declinando dependendo da sua gravidade (PERNETTA, 1954)

A desnutrição se caracteriza pelo estaōo crônico de carência proteica e/ou calórica, ocorrendo diminuição, interrupção ou involução dos parâmetros orgânicos, principiando pelos bioquímicos, sendo seguido pelos funcionais e anatômicos.

A desnutrição é dividida de maneira simplista em dois tipos, em função dos sinais clînicos devidos aos nuitrientes afetados:

a) Kwashiorkor, resultante de insuficiência de aporte proteico;

b) Marasmo, resultante de insuficiente aporte proteico e calórico.

Refere-se que a deficiência calórica sempre acompanha a deficiência proteica e que, praticamente, não existe consumo calórico adequado na deficiência proteica.

A diminuição da ingesta calórica provoca um aumento da excreção nitrogenada resultante do catabolismo proteico pela utilização de novas rotas metabólicas para suprir as necessidades de energia e parece-nos que os organismos mantidos em deficiência calórica crônica, por adaptação reduzem suas perdas calórica, diminuindo suas necessidades energéticas b a s a is. (MUNRO, 1964 appudd 1976; WANMACHER, 1976)

A etiologia da desnutrição é variada e parece incluir baixa renda, meio físico e psicológico insatisfatórios, desconhecimento dos pais sobre cuidados apropriados à criança, além da ausência de tratamento médico.

Relacionando-se também às díficuldades na dietética infantil com erros de julgamento por parte do médico e pelo não seguimento da orientação dada à mãe do paciente, considera-se além disso, que a administração de regime alimentar insuficiente em proteinas e calorias por tempo prolongado, tais como a amamentação por um periodo excessivo, além de mucilagens de cereais e outros, possam contribuir para aistúrbios nutricionais.

Sabe-se que, na desnutrição, tem importância relevante os fatores ambientais, nos quais inclui a desnutrição materna e morbidez, além das condições sócio-econômicas. Segundo alguns autores, é difícil precisar o papel da desnutrição materna, já que nas populações onde a desnutrição é crônica associamse altos indices de infecções e a morbidez e condições sócio-econômicas são capazes de obscurecer os possiveis efeitos na desnutrição. (SORIMSCHAW 1964 appudd SALUM 1976; HEGSTES 1964 appudd SALUM 1976; PERNETTA, 1954; FIORE, 1972; LECHTIG et alii, 1977)

Conforme informações publicadas na V conferência Nacional de Saúde, o coeficiente de mortalidade infantil em Porto Alegre foi de $54,8 \%$ em 1974. (Fonte: Anuário Estatístico do Brasil - IBGE - 1974)

Dentre as principais causas dos óbitos infantis no Brasil, destacam-se as doenças infecciosas associadas à desnutrição.

Em pesquisas de laboratório, demonstrou-se os efeitos da má nutrição na gravidade e duração dos processos infecciosos quer adquiridos naturalmente ou induzidos. Nos casos leves e moderados de má nutrição, os estudos se mostram inconclusivos. (BENEDIT et alii \& MILLER et alii appudd SALOMON 1976; MINER 1955 appudd SALOMON 1976)

Considera-se que na interação do hospedeiro, agente e meio é que são identificadas as causas de uma patologia e que, no caso de doenças nutricionais, o meio tem posição relevante, podendo atuar afetando a disponibilidade de alimentos, os requerimentos nutricionais do hospedeiro e o consumo dos alimen- 
ROSA, M.S.O. e colaboradoras - Como proteger a criança de 0 a 24 meses contra a infecção. Rev. Bras. Ent.; DF. 32 : 271-295, 1979.

tos. (SORIMSHAW 1964 appudd SALUM 1976)

O consumo inadequado de calorias provoca aumento da degradação proteica, o que depleta o organismo de seus elementos básicos dependendo esta depleção da adequada ou nāo adequada ingesta calórica. A desnutriçāo ocorre com maior freqüência em idade de crescimento quando todo o nitrogênio é mobilizado para sintese proteica.

As alteraçōes decorrentes do insuficiente aporte sāo irreversíveis e tão mais intensas quanto maior o tempo de agressāo nutricional. (CRAVIOTTO \& DE LICARDI 1971 appudd SALUM 1976)

Segundo dados coletados por SALOMON (1976), crianças menores de dois anos apresentam infeccōes repetidas a intervalos frequientes. Sendo neste período que a criança atinge a velocidade máxima de seu crescimento, a expoliação proteica e o consumo energético é constante e significativo.

As doenças infecciosas, por interferirem na absorção e utilização dos nutrientes, aumentam as perdas metabólicas. Os estados de má nutrição interferem na resistência do organismo, aumentando sua suscetibilidade a novas agressōes de agentes infecciosos.

A diarréia, pela perda de eletrólitos e nutrientes nas fezes, pode precipitar ou agravar os distúrbios nutritivos na crianças.

O efeito agravante ou espoliativo do estace nutricional pelos processos infecciusos liga-se diretamente à sua gravidade e duração. A grande maioria das crianças sobrevive à infecção e desnutrição com marcado atraso no crescimento físico, desenvolvimento mental e de conduta. (SALOMON, 1976)

\section{4 - Aleitamento materno}

Além da imunidade adquirida e da imunidade natural, a falta do aleitamen- to materno também pode influir na instalação do processo infeccioso.

Já no século XIX, poucas crianças sobreviviam sem o leite materno e, em Londres, estimava-se que de oito crianças privadas do aleitamento natural, sete morriam. (LIMA, 1978)

Começaram, então, a aparecer as "famosas" amas de leite e entre os anos de 1911 e 1916, 58\% de 22 mil crianças americanas recebiam leite materno. (WOODBURY appudd LIMA 1978)

Os avanços da tecnologia vieram a favorecer o leite de vaca, o que é bem evidenciado no trabalho de BAIN appudd LIMA, qual coloca que em 1940, 65\% dos recém-nascidos eram amamentados pelo leite materno; em 1958, 25\% continuavam recebendo leite materno até o sétimo dia de vida. Conclui-se que $\mathbf{7 5 \%}$ dos recém-nascidos já recebem mamadeiras no sétimo dia de vida. Esse percentual parece permanecer até hoje.

Além do avanço tecnológico, a emancipação feminina também favoreceu o uso de leite de vaca, uma vez que a mulher, atualmente, não se prende mais em casa, procurando cada vez mais o trabalho fora. Além disso, passou a ser moderno o fato de usar leite em pó para os recém-nascidos, pela importância dada a este.

Atualmente, intensificaram-se as pesquisas obre o leite materno, chegando-se à conclusão de que é ele o melhor alimento para o recém-nascido, dependendo o sucesso do aleitamento natural, da secreção da mama e da freqüência da sucção pelo bebê.

E no leite materno, que o recémnato encontra o alimento ideal pois sua composição química perfeita corresponde às necessidades nutricionais e atende às condiçōes particulares da digestão e do metabolismo. O leite materno possul $87,8 \mathrm{~g} / 100 \mathrm{~cm}^{3}$ de água, $1,5 \mathrm{~g} / 100 \mathrm{~cm}^{3} \mathrm{de}$ proteínas, $6,5 \mathrm{~g} / 100 \mathrm{~cm}^{3}$ de hidratos de carbono, $4,0 \mathrm{~g} / 100 \mathrm{~cm}^{3}$ de gordura e 6,2 $\mathrm{g} / 100 \mathrm{~cm}^{3}$ de sais e seu valor energético 
ROSA, M.S.O. e colaboradoras - Como proteger a criança de 0 a 24 meses contra a infecção. Rev. Bras. En̊.; DF. 32 : 271-295, 1979.

é de cerca de 70 calorias $/ 100 \mathrm{~cm}^{3}$. (PERNETTA, 1955)

O leite materno é de fácil digestāo pois as suas proteínas são representadas, praticamente, por $2 / 3$ de lacalbumina e $1 / 3$ de caseína. A caseína precipita em flocos tênues e suaves, sendo mais fácil e rápida a sua digestāo. (PERNETTA, 1955; ESMERALDO, 1973)

Além disso, a glândula mamária já no terceiro ou quarto dia após o parto é capaz de produzir o colostro, que é rico em proteínas, pobre em lactose, com gorduras semelhantes às do organ!smo da criança, contendo o dobro dos sais minerais do leite materno e, possuindo fermentos digestivos, vitaminas e substâncias imunizadoras. (FIORI, 1972)

FEITAS e FIORI (1974) citam várius fatores des resistência que possuem ação bacteriostática presentes no leite materno:

\section{COMPONENTES DO LEITE MATERNO MECANISMO DE AÇAO}

Fator de crescimento do lacto-bacilus bifidus
Interferência com a colonizaçāo intestinal de bactérias patogênicas

Fator anti-estafilocócico

Inibe o crescimento do estafilococo

IgA (principalmente) e outras imunogiobulinas
Anticorpos protetores para o intestino e o trato respiratório

Lactoperoxidade - $\mathrm{H} 2 \mathrm{O} 2$ - Tiocinato Destrói o estreptococo

Lactoferrina

Leucócitos
Destrói as bactérias por açāo quelante sobre o ferro

Fonte: FRETTAS \& FIORI - Pesquisa Médica - 1974, p. 351. 
ROSA, M.S.O. e colaboradoras - Como proteger a criança de 0 a 24 meses contra a infecçāo. Rev. Bras. Enf.; DF. 32 : 271-295, 1979.

Segundo informes da Secretaria de Saúde do Rio Grande do Sul mostrado por CUNHA (1976), no verão de $74 / 75$, das 4.390 hospitalizações por desidratação, $49,7 \%$ não havia recebido leite materno (2.182 crianças): $30,4 \%$ ou 1.336 crianças haviam recebido até um mês e apenas $5,4 \%$ ou somente 237 crianças haviam recebido leite materno por mais de 3 meses.

Fatos como estes levam à conclusão que o leite materno é preventivo do binômio infecção/desnutrição. Em familias de baixo poder aquisitivo, o desmame precoce é, na maioria das vezes uma condenação à morte. (CUNHA, 1976).

A partir das colocações anteriores, conclui-se ser de inestimável importância o retorno ao aleitamento materno, uma vez que ele constitui, na orientação alimentar, o ponto mais importante, não só ern termos de saúde, como também, em termos econômicos (NÓBREGA, 1977).

\section{5 - Higiene corporal e ambiental}

Além dos fatores já citados anteriormente, parece de suma importância analisar as condições higiênicas corporais e ambientais, que poderão concorrer para a instalação e desenvolvimento de processos infecciosos.

\section{HIGIENE CORPORAL:}

Em pediatria, as ações preventivas devem abranger a totalidade dos cuidados sanitários da criança, envolvendo os problemas comunitários. Dentre estes cuidados encontram-se os que se referem à higiene. Esta é definida como a maneira pela qual conserva-se a saúde e previne-se a doença (CESARINO JtNIOR, 1967; HAGGERTY, 1970).

A higlene é focalizada como, em grande parte, o resultado do desenvolvimento de hábitos que iniciam ao nascer e continuam durante toda a vida. A formaçāo de hábitos consiste numa estimu- lação da criança pelos pais, até que esta chegue a um nivel de independência sendo, sempre que possível, desprezados os aspectos triviais. importante, para a criança atingir esse objetivo, o exemplo paterno: praticar o que aconselha e, ao mesmo tempo, respeitar a individualidade da criança, permitindo a criatividade dentro cio próprio desenvolvimento (LAUPUS, 1970).

Muitos aspectos contribuem para a formação dos hábitos, conforme o mesmo autor. $O$ primeiro destes seria a regularidade do horário de deitar-se, assim como sua manutenção. Um ambiente adequado, sem estímulos, na hora de deitarse e o carinho e o afeto dispensado pelos pais à criança e muito contribuem para que este hábito torne-se sadio.

Outro aspecto refere-se ao controle dos esfíncteres anal e vesical que é adquirido, sem pressões paternas, por volta dos 2 a 3 anos. Esforços paternos anteriores a isto, são desastrosos pois trazem problemas psíquicos para a criança, bem como, para o relacionamento paisfilho. Deve ocorrer, isto sim, e no periodo adequado, uma estimulação para sentar no urinol ou manobras que levem a criança a despertar para essa necessidade.

Este autor salienta ainda, que em um ambiente físico adequado, toda a criança normal executa o exercício e a atividade muscular necessária para seu crescimento e desenvolvimento sadio. Quando maior e, principalmente, quando começar a caminhar os país devem proporcionar-lhe um ambiente físico adequado: superfícies planas, passeios...

Ressaltando ainda este enfoque: a partir da segunda quinzena de vida, a criança pode iniciar seus passeios. No entanto, deve ser evitado: ruas com muito trânsito, pó, contato con animais e com crianças doentes. $O$ sol é considerado um complementc do banho de água, de ar e de luz (ALCANTARA, 1974).

Ainda sobre este aspecto, o sol e o ar livre são essenciais para a saúde da 
ROSA, M.S.O. e colaboradoras - Como proteger a criança de 0 a 24 meses contra a infeç̧ăo. Rev. Bras. Enf.; DF. 32 : 271-295, 1979.

criança. recomendável em qualquer láade, as brincadeiras ao ar livre desde que o tempo o permita e o vestuário seja adequado. Este deve permitir ampla liberdade de movimentos, pois a sua movimentação espontânea constitul a melhor ginástica. Deve ser cômodo, folgado, fácil de vestir e despir, além de ser variável de acordo com a temperatura ambiente (LAUPUS, 1970; ALCANTARA, 1974).

O banho constitul outro aspecto imprescindível à boa saúde da pele da criança. Deve ser diário e anterior às refeiçōes, proporcionanaio uma oportunidade para a inspeção do corpo da criança. O cuidado higiênico com as fraldas deve ser ressaltado. Estas devem ser trocadas sempre que molhadas ou sujas. Nesta troca a pele deverá estar bem seca e higienizada. Além do banho e da higiene com as fraldas, é importante a formação do hábito de lavar as mãos antes das refeiçōes, a limpeza dentárla e certa responsabilidade no cuidado com o vestuário (LAUPUS, 1970; ALCANTARA, 1974).

Outro aspecto importante é o que se refere à saúde oral da criança, destacada por VIEGAS (1974). Este cuidado deve ter início na gestação através da ingestão de uma dieta equilibrada e acrescida de flúor, pois os dentes formam-se $e$ calcificam-se na vida intra-uterina. A criança malor, deve ser administrado flúor pois os dentes permanentes têm seu esmalte formado e calcificado até os 16 anos de Idade.

Para ALCANTARA (1974) a habitação é outro aspecto a ser ressaltado por constituir uma proteção direta na higlene da criança. Esta deve ser ampla, ensolarada, bem ventilada, construía em terreno seco, ter rede de esgotos, distribuição de água e boa limpeza; não ser entulhada de móveis e não ser próxima a ruidos e poeiras.

Em contrapasição sugere CASSEL 1971 appud OMS, 1976 que a relação entre a habitação e a saúde pode ser multo indireta e que a interação habitação/meio ambiente por si só não exercem malefícios para a saúde, partindo do princípio que se desconhecem e não se alteram os processos que intervêm.

Considerando os aspectos salientados, torna-se importante a realizaçāo das medidas preventivas para assegurar um bom desenvolvimento psíquico e físico à criança. São importantes pois Impedem ou diminuem a incidência da infecção na infância.

\section{HIGIENE AMBIENTAL:}

Saneamento é a modificaçảo que o homem pode executar no melo amblente, deletério ou que possa tornar-se, de maneira que este se torne mals propicio para o bem-estar físico, mental e social, segundo citação da OMs (1976).

Os assessores técnicos da OMs colocam que. segundo HUNTER (1960), com extrema freqüência o nível de infecções é inversamente proporcional ao nível de saúde das comunidades. Colocam ainda que para grande parte das enfermidades transmissivelis c saneamento básico é o melo mais econômico, racional e, talvez, o único de combatê-las preventivamente.

Para a confirmação destes dados, em um estudo realizado em 78 cidades dos EUA houve uma diminuição da taxa de mortalidade por febre tifólde, de 20,54 para 0,15 por 100.000 habitantes, quando colocada à disposição da população água pura (AMERICAN WATER WORK8 ASSOCIATION 1950 appudd OMS. 1976).

Com todos estes estudos e constataçōes, a OMS (1976) considera comprovado que o saneamento básico com 0 apolo da tecnologia protege o Individuo e a comunidade das enfermidades transmitidas pela água, por alimentos contaminados ou por insetos vetores.

Ressalta que esta proteção, relacionada ao abasteci mento de água, deve fornecer uma substância de qualidade superior (composição química não alterada 
ROSA, M.S.O. e colaboradoras - Como proteger a criança de 0 a 24 meses contra a infeccåo. Rev. Bras. Ent.; DF. 32 : 271-295, 1979.

e não estar abaixo das funçōes ou propósitos para os quais seria apropriada em seu estado natural), não somente para fins culinários ou para beber, mas também, para a higiene pessoal, lavagem e limpeza pública. Tem por objetivo uma água de qualidade pura e em quantidade suficiente para o uso doméstico, público, industrial e recreativo. Para o consumo humano, parece lógico, reservar a de melhor qualidade. Portanto, deve-se ter em mente que o melhor consumo de água é originado de uma rede controlada por autoridades sanitárias, onde esta será tratada por processos que garantam sua composição inalterada.

No Brasil, segundo o Anuário Estatístico do Brasil - IBGE (1974), 52,10\% dos domicilios urbanos têm água encanada, enquanto $47,90 \%$ não têm. Em relação aos domicillios rurails, apenas $5,6 \%$ têm água encanada e os restantes $\mathbf{9 4 , 4 \%}$ não possuem. Indice este que comprova a má qualidade da água consumida pelos brastleiros, levando a índice alto de contaminaçāo.

Quanto à eliminação de excretas e resíduos líquidos, os esgotos; a proteção constitui-se em nāo serem acessívels ao homem e aos vetores animados, nāo polúrem a água e o solo e nåo acarretarem outros inconvenientes, como mau odor e mau aspecto. importante que aconteça a sua ellminaçāo e o objetivo bésico 6 nảo haver contato direto ou Indireto com o homem. Porém, quando não 6 possível um sistema de esgotos, é importante que as medidas sanitárias atenuadoras tenham uma supervisão eflciente. O Ideal, na realidade, constitui uma rede de esgotos com boa canalizaçäo.

Begundo o IBGE (1974), as esgotos sanitários brasileiros foram divididos em domicillos urbanos e rurals. Dos domićllios urbanos $24,1 \%$ são ligados à rede geral; $16,6 \%$ possuem fossa séptica; $35,7 \%$ possuem fossa rudimentar; $4,8 \%$ outro tipo de escoamento e $18,8 \%$ nāo possuem nenhum tipo de esgoto. Dos domicilios rurais, $0,2 \%$ estão ligados à rede geral; $1,8 \%$ possui fossa séptica; $18,2 \%$ possuem fossa rudimentar; $3,4 \%$ outro tipo de escoamento e $\mathbf{7 6 , 4 \%}$ não possuem nenhum tipo de escoamento. Portanto, nos domicílios urbanos predominam os esgotos sanitários ligados à rede geral, segundo o preconizado pela OMS, enquanto que nos domicilios rurais as condições são precárias pols a grande maioria não possul nenhum tipo de escoamento.

Outra proteção ambiental à saúde humana é o destino e tratamento dos resíduos sólidos: o lixo. Há indícios que estes resíduos aumentam, consideravelmente, em todo o mundo. Segundo Grupo Científico 1967 appudd OMS 1976, sobre o tratamento e evacuação de dejetos, as cifras destes resíduos urbanos estão ao redor de $600 \mathrm{~kg}$, e com um aumento anual de $1,2 \%$.

Aumentam o perigo à saúde do homem, o encaminhamento nāo adequado destes resíduos por criarem condiçōes favoráveis às moscas, mosquitos, roedores e outros vetores de enfermidades. Além disto, contaminam a água, o ar e o solo; deterioram o melo ambiente salubre. Por uma atuaçāo eficiente entende-se: sistema adequado de transporte, instalação para o tratamento dos dejetos e instalaçōes para a descarga sanit́ária no ambiente (OMS, 1976).

Não menos importante à saúde humana, como medida preventiva ambiental, segundo salienta o comitê de expertos em inseticidas, 1970 (appudd OMs 1972), é o controle dos vetores, principalmente, insetos e roedores. Isto inclui um controle ambiental, dentro de métodos ecológicos, através da modificaçāo do meio, permitindo a sua reprodução, mas, impedindo a sua proliferaçāo.

O comitê de expertos em aspectos microbiológicos da higiene dos alimentos, 1968, e a comissão mista do codex allmentarius, 1969 appudd OMS 1976 ressal- 
ROSA, M.S.O. e colaboradoras - Como proteger a criança de 0 a 24 meses contra a infeçå. Rev. Bras. Enf.; DF. 32 : 271-295, 1979.

ta ainda a higiene dos alimentos. Tornase importante a sua proteção constante, bons hábitos higiênicos, armazenamento de alimentos suscetivels, limpeza e tratamerito, inspeçīo e controle sanitário dos alimentos.

Os técnicos da OMS (1976) ressaltam ainda o impedimento, sempre que possível, da contaminação do próprio ar por metodos que o contaminem menos ou com uma supervisão adequada das fontes potencigis de contaminacāc. Isto muito deixa a desejar, pois é gritunte a poluição cada vez maior do nosso ar, assim como, a falta de controle absoluto por autoridades sanitárias no Brasil.

\section{METODOLOGIA}

\section{1 - Material e métodos}

A fim de responder às indagaçōes à incidência e aos fatores predisponentes de infecção em crianças, seguiam-se diferentes etapas. Para tanto descreve-se a população, os instrumentos, a coleta de dados e o tratamento estatístico.

Obteve-se os seguintes resultados:

- Incide̊ncia de infeç̧ão

- Faiza etária mais atingida (0 a 24 meses)

- Primeira internaçāo

- Reinternação

- Vacinaçāo

- Aleitamento materno

- Rede de água

- Rede de esgoto

\section{2 - Populaçáo}

Para este estudo utilizou-se a população do Hospital da Criança Santo Antônio de Porto Alegre, cujas disponibilidades eram de 185 leitos, pertinentes a nove unidades, distribuidos entre as faixas etárias de 0 a 15 anas, de ambos os sexos, portadores de diferentes tipos de patologias, pertencentes a diversos niveis sócio-econômico-culturais e procedentes da capital e do interior do Estado.

\section{3 - Instrumentos}

A partir de observações assistemáticas formulou-se um estudo exploratório prévio com a finalidade de confirmar impressões e observações de campo.

Planificou-se o estudo prévio baseando-se nas faixas et́́rias exdstentes na populaçảo e nos diversos fatores que poderlam afetar a criança (anexo 1).

Os dados para este plano foram colhidos na revisāo de 185 prontuários, sendo aproveitados 172, nảo apresentando, os outros, informações suficientes.

$\begin{aligned} 76,74 \% & (132 \text { crianças) } \\ 79,4 \% & (108 \text { crianças) } \\ 66,2 \% & (114 \text { crianças) } \\ 33,2 \% & (57 \text { crianças) } \\ 0,6 \% & (\text { (s/informação }) \\ 40,7 \% & (70 \text { receberam) } \\ 53,5 \% & (90 \text { não receberam) } \\ 5,8 \% & (10 \text { sem informação) } \\ 50,8 \% & (86 \text { receberam) } \\ 33,7 \% & (56 \text { não receberam) } \\ 16,8 \% & (28 \text { sem informação) } \\ 68 \% & (117 \text { possuem) } \\ 25,6 \% & (44 \text { não possuem) } \\ 6,4 \% & (11 \text { sem informação) } \\ 49,4 \% & (85 \text { possuem) } \\ 43,0 \% & (74 \text { não possuem) } \\ 7,6 \% & (13 \text { sem informação) }\end{aligned}$


ROSA, M.S.O. e colaboradoras - Como proteger a criança de 0 a 24 meses contra a infecçāo. Rev. Bras. Enf.; DF. 32 : 271-295, 1979.

- Sexo masculino

- Sexo feminino

$\mathrm{Na}$ faixa etária de 0-24 meses:

- Sexo masculino

- Sexo feminino

- Infecções nesta faixa etária

De acordo com os resultados do estudo exploratório prévio, detalhado acima, de selecionada revisão bibliográfica e de entrevistas com seis especialistas das áreas de Nutrição, Pediatria, Microbiologia, Planejamento e Saúde Pública, elaborou-se um instrumento.

Através da análise, pode-se constatar a maior incidência de infecção na faixa etária de 0 a 2 anos, além de dados significativos nos aspectos de vacinação, aleitamento materno, rede de água e esgoto. Em decorrência, limitouse o instrumento à esta faixa etária e a portadores de infecção, sendo este compasto de sete partes: identificação, vacinação, nutrição, hidratação, saneamento, higiene corporal e outras informações.

$\mathrm{Na}$ identificação procurou-se obter informações de caráter geral sobre a criança e a família.

Na vacinação, objetivou-se constatar a aplicação do esquema de vacinação próprio para a faixa etária.

Dentro da nutrição, enfocou-se o aleitamento materno e os tipos de nutrientes adequados para a idade.

Quanto à hidratação, pesquisou-se a freqüência e o tipo de líquido administrado.

No saneamento, procurou-se verificar as condições do meio ambiente sanitário.

$\mathrm{Na}$ higiene corporal, indagou-se sobre os hábitos higiênicos e vestuário.

As outras informações tinham caráter complementar.

$O$ instrumento foi elaborado sob forma de questionário, com perguntas objetivas que levavam a resposta suscintas e diretas.

$\begin{array}{ll}65,1 \% & (112 \text { crianças }) \\ 34,9 \% & (60 \text { crianças }) \\ 65,4 \% & \text { ( } 89 \text { crianças }) \\ 34,6 \% & (47 \text { crianças }) \\ 79,4 \% & (108 \text { crianças })\end{array}$

Com o objetivo de verificar a validade do instrumento foi realizada a testagem do mesmo em $20 \%$ da população, sendo necessário a reformulação de alguns aspectos, para finalmente obter-se o instrumento definitivo.

\section{4 - Coleta de dados:}

A população utilizada para aplicação do instrumento definitivo limitou-se a crianças hospitalizadas (através das mães), cuja faixa etária oscilava de 0 a 2 anos e eram portadores de infecção. Realizou-se a coleta de dados, nos períodos de visita, entre 13:30 e 14:30 horas, procurando-se abreviar ao máximo a entrevista, levando-se em conta o curto espaço de tempo da visita (durante o mês de maio de 1979).

A aplicação do questionário ficou a cargo de um grupo de alunos da disciplina de Pediatria, os quais treinaram previamente os procedimentos, visando uniformização nas entrevistas.

A distribuição dos elementos foi aleatória, agrupando dois ou três alunos por unidade.

O entrevistador escolhia ao acaso a mãe a ser entrevistada, identificando-se e explicando a finalidade do questionário. A seguir, eram formuladas as questões, de modo a não induzir a respostas, sendo a mesma assinalada na folha, pelo entrevistador.

O tempo médio utilizado para a aplicação do instrumento foi de quinze minutos.

Em seqüência, objetivando complementação das informações, fez-se revisão do prontuário. 
ROSA, M.8.O. e colaboradors - Como proteger a crianga de 0 a 24 meses contre infeçå. Rev. Bras. The.; DF. 82 : 271-295, 1979.

\section{5 - Tratamento estatistico}

A partir dos dados coletados, utillzou-se medidas de frequencia e percentagem como critério estatístico.

Numa primeira etapa confeccionouse tabelas em ámbito geral, nảo discriminando por faixa etárla os itens abordados.

Frente ao pequeno detalhamento apresentado nesta primeira tabela, passou-se à execuçāo de novas tabelas, nas quals delimitou-se por faixas etérlas, relacionando-as com as diferentes itens.

\section{6 - Limitações do estudo}

Questionando-se a fidedignidade dos dados coletados no desenvolvimento do trabalho, acredita-se que, provavelmente, os resultados nảo possam ser generalizsdos para todo o pais, pols as diversas regiōes deste, apresentam diferenças significativas nos aspectos climáticos e nos níveis sócio-económico-culturais de sua população.

Durante o desenvolvimento do tra balho, deparou-se com dificuldades na elaboraçāo das questōes, no que se refere à adequação da terminologia ao nível cultural, das entrevistadas, na tentativa de formular questōes acessiveis ao entendimento das mesmas.

Outro aspecto a ser apreciado fol 0 estado emocional das entrevistadas, devido a intercorrência de fatores externos, tais como estado de saúde da criança e problemas famlliares, desviando sua atenção.

A desconfiança da entrevistada pode ser mencionada como fator limitante, devido ao medo de comprometer, através de suas respostas, os beneficlos socials prestados na internaça.

A comunicaçāo Inadequada poderá ter dificultado a compreens gunta e a verbalizagho da resposta,
Outro aspecto observado fol a nảo coincidência entre o transmitido e a realidade observada.

\section{ANALISE E DISCUSSAO DOS.DADOS}

Nesta parte, sāo analisados e discutidos os resultados obtidos através da apllcaçāo do instrumento.

Os resultados sāo apresentados em números absolutos e porcentagem, encontrando-se distribuidos nos segulntes itens: caracterizaçāo da populaçāo; $1 \mathrm{mu}$ nidade; vacinaçäo; aleitamento materno; nutriçāo; higlene corporal e ambiental.

Com os dados obtidos, foram elaboradas quarenta e sete tabelas, as quals são apresentadas em anexo, sendo 80mente citadas no decorrer da análise.

\section{1 - Caracterizeçaio da populaçâo}

As crianças que compōem a população estudada encontram-se na faixa etária de zero a vinte e quatro meses, tendo esta sido delimitada através de Investigação prévia.

Constata-se que 53,77\% das crianças do grupo eram do sexo masculino, sendo que a maior ocorrência fol na falxa de 18-21 meses e, 46,23\% eram do sexo feminino.

Observa-se que $64,15 \%$ das crianças apresentaram ao nascer peso igual ou superior a três quilos. A distribuição deste peso mostrou-se equitativa nas diferentes faixas etárias. Considera-se, então, que a maioria das crianças apresentou peso ao nascer, dentro dos limitos de normalidade. Entretanto existe um percentual significativo de crianças que apresentaram peso inferior a dols quillos e quinhentos gramas.

Fim relação ao peso atual, constderando que a maiorla das crianças apresentou 20 nascer peso igual ou supertor a três quilos, é observado que na falra etária de 0-15 meses as crlanģas apre- 
ROSA, M.S.O. e colaboradoras - Como proteger a criança de 0 a 24 meses contra a infecçảo. Rev. Bras. Enf.; DF. 32 : 271-295, 1979.

sentam "déficit" de peso, sendo que na faixa de 15-24 meses o valor do peso está dentro dos limites da normalidade.

$O$ percentual das mães que tiveram gravidez a termo foi de $83,01 \%$ e $\mathbf{7 9 , 2 4 \%}$ das mesmas tiveram parto normal.

Verifica-se que $52,83 \%$ das mães e $48,11 \%$ dos pais das crianças deste grupo, encontram-se na faixa etária de 20-30 anos. Faixa esta, que parece adequada para fase reprodutora, não caracterizando situação de alto risco.

A miaoria dos genitores apresenta grau de instrução correspondente ao primeiro grau incompleto. E, pois, observado o baixo grau de instrução dos mesmos.

Em relação à atividade dos genitores, verifica-se que $49,00 \%$ dos pais exercem trabalho braçal e $\mathbf{7 3 , 5 8 \%}$ das mães não exercem atividades fora do lar. Foi observado que $69,81 \%$ das mães relatam prestar cuidados à criança.

Levando-se em conta que na maioria dos casos é a mãe quem presta os cuidados à criança, era de se esperar bom estado de higiene e saúde das crianças, o que não é confirmado pelas observaçōes assistemáticas realizadas.

Das crianças estudadas, a maioria não apresenta irmão menores, $37,23 \%$ não apresentam irmãos maiores e $34,90 \%$ apresentam de um a dois irmãos maiores. Percebe-se, através destes resultados, que os grupos familiares não possuem prole numerosa.

A maioria dos grupos familiares apresenta de 4-6 dependentes de sua renda. Considerando-se que a renda familiar concentra-se na faixa de 1-3 salários mínimos, é possível classificar como baixo o nível sócio-econômico-cultural da população estudada.

Quanto à avaliação médica periódica, $\mathbf{4 5 , 2 8 \%}$ das māes das crianças relatam realizar avaliação médica regularmente e $45,28 \%$ procuram assistência médica somente quando a criança está doente. $\mathrm{Na}$ falra de 0-6 meses, a maioria das mães informou fazer avaliação periódica da crlança, enquanto que no período mais tardio (de 6-9 e ae 15-24 meses) as mães procuram recurso médico somente quando a criança se encontra doente.

Nota-se, pois, a importância em orientar as mães da necessidade da regularidade e continuidade da avaliaçāo médica periódica, o que permitirá detectar precocemente processos mórbidos, assegurando evolução normal ảa saúde da criança.

Com referência às causas da internação atual, obteve-se maior ocorrência de internaçōes por infecçöes de vias aéreas e por distúrbios nutritivas agudos.

\section{2 - Imunidade}

Nos resultados obtidos, constatou-se que $16,04 \%$ da população estudada era de prematuros em relação à idade gestacional e que $14,16 \%$ àa população apresentou ao nascer peso inferior a dois quilos e quinhentos gramas. Estes dados parecem significativos quando se refere à profilaxia de infecçōes em crianças pois é sabido que a prematuridade é fator concorrente para desencadear estado infeccioso devido à imaturidade imunitária do pré-termo.

Observa-se que $53,77 \%$ do total da população estudada é constituída por crianças do sexo masculino, sendo que na faixa dos 18-21 meses aparece a maior ocorrência de meninos afetados, enquanto que na faixa etária de 9-12 meses há uma maior incidência de meninas.

Estes dados não parecem tão significativos quando comparados com a revisāo da literatura. Entretanto, ao observar os resultados obtillas no estudo prévio, vê-se, em crianças da mesma faixa etária (de zero a vinte e quatro meses), maior ocorrência de infecçōes no sexo masculino.

\section{3 - Vacinaçāo}

Verifica-se que $47,17 \%$ da população alvo não havia sido vacinada, sendo a maior ocorrência de nāo vacinados na 
ROSA, M.S.O. e colaboradoras - Como proteger a criança de 0 a 24 meses contra a infecçăo. Rev. Bras. En^.; DF. 32 : 271-295, 1979.

faixa etária de 0-3 meses e a de menor na faixa de 21-24 meses.

t observado que nas faixas de 6-9, de 9-12, de 15-18 e de 18-21 meses não houve nenhum caso ae vacinação completa. Do total das crianças analisadas, apenas $\mathbf{8 , 5 0 \%}$ estavam com esquema vacinal atualizado.

Ao agrupar as crianças não vacinadas com as de vacinação incompleta, obtém-se o significativa percentual de $76,40 \%$.

Estes dados confirmam a literatura consultada, de que a não imunização ou a imunização inadequada, concorrem para a desproteção imunitária da criança.

\section{4 - Nutriçāo:}

Observa-se que $36,80 \%$ das crianças do grupo apresentaram uma internação anterior. Em relação às causas mais freqtentes obteve-se: distúrbios nutritivos crônicos, agudos e infecçōes de vias aéreas. Examinanoio-se as faixas etárias, verifica-se que os distúrbios nutritivos crônicos ocorreram apenas nas faixas de 0-3 e de 3-6 meses. Os distúrbios nutritivos agudos foram as causas que mais ocorreram nas faixas de 3-6, 6-9 e de 12-24 meses. As infecçōes de vias aéreas ocorreram nas faixas de 0-12 e de 21-24 meses.

Vê-se que $16,04 \%$ da população estudada teve duas internações anteriores. Nestas internaçōes as causas mais freqüentes foram: infecçōes de vias aéreas e distúrbios nutritivos agudos. Não houve ocorrência de distúrbio nutritivo crônico. As infecçōes de vias aéreas foram as causas mais freqüentes nas faixas de $\mathbf{0 - 3}$, 3-6, 12-15 e 15-18 meses. Os distúrbios nutritivos agudos foram mais freqüentes nas faixas de 6-9 e 18-21 meses.

Fol verificado que $9,43 \%$ do grupo estudado apresentaram três internaçōes anteriores. Atualisando as causas destas internaçōes, observa-se que as mais freqüentes foram: infecçōes de vias aéreas e distúrbios nutritivos agudos. Os distúr- bios nutritivos crônicos aparecem com menor freqüência. Os distúrbios nutritivos crônicos ocorreram apenas na faixa de 6-9 meses. Os distúrbios nutritivos agudos apareceram como causa nas faixas de 3-6, 12-15 e 15-18 meses, e as infecçōes de vias aéreas nas faixas de 3-6, 6-9 e 12-15 meses.

Considerando-se a faixa .etária de zero a vinte e quatro meses, parecem relevantes os dados referentes ao número de internaçōes anteriores. Nestas internações as causas mais freqüentes foram infecçōes de vias aéreas, distúrbios nutritivos agudos e distúrbios nutritivos crônicos, sendo que nas diferentes internações a incidência de distúrbios nutritivos agudos foi maior a partir do décimo quinto mês, as infecções de vias aéreas tiveram öistribuição irregular e distúrbios nutritivos crônicos antes dos doze meses (zero a nove meses).

Parece provável que os distúrbios nutritivos e as infecções de vias aéreas concorrem na depleção orgânica, podendo levar a outras internaçōes, pois é sabido que as distúrbios crônicos e/ou agudos e os processos infecciosos debilitam o organisco por afetarem o estado nutricional e diminuirem a resistêncla do indivíduo.

Os distúrbios nutritivos crônicos ocorreram mais freqüentemente no período de 0-9 meses, o que poderia estar relacionado com o possível desmame precoce, associado à dificuldade desta população em adquirir alimentação de equivalente valor nutritivo ao leite materno.

Já os distúrbios nutritivos agudos ocorreram mais a partir do décimo quinto mês, o que poderia estar relacionado com a incorreta higiene das mamadeiras, da preparação dos allimentos e com talhas no saneamento básico da população.

As infecçōes de vias aéreas tiveram distribuição irregular nas diversas falxas etárias, talvez por influência climática, condiçōes do ambiente físico e estado nutricional, fatores estes que agem independentes da idade. 
ROSA, M.S.O. e colaboradoras - Como proteger a criança de 0 a 24 meses contra a infeç̧̊̊o. Rev. Bras. Ent.; DF. 32 : 271-295, 1979.

Quanto aos antecedentes mórbidos das crianças, os mais freqüentes foram: infecçōes de vias aéreas superiores, febres e diarrélas.

Observa-se que as infecçōes de vias aéreas superiores foram os antecedentes de maior ocorrêncla em todas as faixas etárias. A febre é a segunda maior ocorrência nas faixas de 6-9, 9-12 e 15-18 meses. Nas faixas de 0-3, 3-6, 12-15, 18-21 e 21-24 meses, esta posição é ocupada pela diarréia.

Percebe-se pelos dados acima a interrelação entre as causas de internações anteriores mais freqüentes com os antecedentes mórbidos que mais ocorreram.

Quanto ao tratamento dispensado à criança, a maioria das mães relata que a criança recebeu atendimento médico, sendo o item mais freqüente em quase todas as faixas etárias, com exceção da faixa de 18-21 meses, onde os itens médico, caseiro ou médico/caseiro obtiveram freqüências idênticas.

Tendo em vista os resultados obtidos quanto ao número de internaçōes e considerando o possivel envolvimento da mãe frente à hospitalização da criança, questiona-se o valor dos resultados acima referidos.

Verifica-se que as infecçōes que, mais freqüentemente, causaram internaçōes atuais foram: infecçōes de vias aéreas e distúrbios nutritivos agudos. As maiores incidências de infecçōes de vias aéreas ocorreram nas faixas de 0-3, 12-15, 18-21 e 21-24 meses. Nas faixas de 3-6, 9-12 e 15-18 meses os disturbios nutritivos agudos superam as infecçōes de vias aéreas.

A investigação foi realizada em população cuja internação ocorreu por processo infeccioso, sem que houvesse preocupação com as causas das internaçōes anteriores. Entretanto, face aos resultados obtidos, constatou-se que as infecçōes de vias aéreas e os distúrbios nutritivos agudos eram as causas mals frequientes tanto nas internaçōes anteriores quanto nas atuals.
Visto o significativo percentual de internaçōes e reinternaçōes por infecções na população estudada, presume-so que o estado nutricional destas crianças encontra-se alterado, predispondo-as a novos processos infecciosos, instalandose entāo o círculo vicioso: DESNUTRIÇAOO-INFECÇĀO.

Relacionando-se o percentual de baixo peso ao nascer (inferior a dois quilos e quinhentos gramas), ao percentual de pré-termos em relação a idade gestacional, verifica-se ocorrência de significativa prematuridade e, tendo em vista as condiçōes sócia-econômicas da população, parece pouco provável que estas crianças tenham um bom crescimento pondo-estatural.

Em relação ao tipo de leite empregado no preparo das mamadeiras, e metade do número de mães das crianças informou utilizar leite de vaca e $39,62 \%$ utilizar leite em pó.

Quanto aos outros elementos que entram no preparo das mamadeiras, $30,19 \%$ das mães das crianças relataram usar mucilagem (água de arroz ou água de aveia) e $24,53 \%$ não utilizam nenhum outro elemento. As demais usam elementos diversos.

No que se refere aos componentes da alimentação, observa-se que na faixa de 0-3 meses a alimentação é essencialmente láctea e na faixa de 3-24 meses, notadamente, a dieta alimentar é diversificada.

Considerando que a maioria da população estudada apresentou ao nascer peso Igual ou superior a três quilos, observase que s crianças da faixa etária de 0-15 meses apresentam "déficit" de peso enquanto que nas da faixa de 15-24 meser o valor do peso etá dentro dos limiles da normalidade.

Pelas observaçōes assistemáticas na população investigada e pelos dados relativos ao peso atual das crianças, parece passível avaliar como deficiente estado nutricional das mesmas. Esta deficiência pode estar associads à inado- 
ROSA, M.8.O. e colaboradoras - Como proteger a crianga de 0 a 24 meses contra a Infecgăo. Rev. Bras, Enf.; DF. 32 : 271-295, 1979.

quada ingesta allmentar tanto qualitativa quanto quantitativa, retardando o desenvolvimento pondo-estatural e favorecendo o processo desnutrição-infecção.

\section{5 - Aleitamento materno}

De acordo com os resultados obtidos, $88,68 \%$ da populaçäo recebeu aleitamento materno. Os percentuals foram significativos em quase todas as faixas etárias, com exceção da faixa de 6-9 meses.

No que se refere ao tempo de aleitamento materno fol constatado que a maloria das crianças recebeu leite materno no periodo de 0-6 meses. Em todas as falxas etárias este período é 0 de maior ocorrência, com exceção da faixa de 15-18 meses.

Ao examinar os resultados referentes ao aleitamento artificial, verifica-se que na faixa de 3-24 meses todas as crianças recebem aleitamento artificial, sendo que na falxa de de 0-3 meses, apenas duas crianças näo o recebem.

Avaliando as condiçōes sócio-econômico-culturais da população estudada, parece correto considerar como desmame precoce o período de seis meses, pois esta populaçāo, provavelmente, não apresenta recursos para substituição alimentar qualitativamente semelhante ao leite materno. Estas colocaçōes permitem caracterizar como precoce o desmame destas crianças. Observa-se, também, que o aleitamento artificial é antecipado e, possivelmente, inadequado devido às condiçōes econômicas, higiênicas e ao desconhecimento materno.

\section{6 - Higiene corporal e ambiental}

Em relaçāo aos cuidados higlênicos dados à criança, a malor parte das mães utiliza água parada para o banho. A maloria das mesmas relata que o banho é diário, tanto nos dias frios quanto nos dias quentes. observado que nos dias quentes $33,02 \%$ das crianças tomam banho mais de uma vez por dia e em dias frios $31,13 \%$ tomam banho de dols em dols dias.

A quase totalidade das crianças estudadas usa fraudas. Apenas $21,72 \%$ das mães informam efetuarem a troca das fraldas em ocasiāo adequada (quando suja, quando molhada ou após a mamada). Quanto à higlene perineal na troca das fraldas a maioria das mães refere realizá-la.

Quanto à higiene das fraldas, 25,47\% das mães utilizam água e sabão comum e $21,70 \%$ utilizam água e sabão neutro. Considera-se estes métodos adequados, uma vez que é o enxagüe correto que auxiliará na prevençāo da dermatite amoniacal.

Através de observaçōes assistemát1cas, coloca-se em dúvida a veracidade das informaçōes acima, pela constatação das deficientes condiçōes higiênicas das crianças, assim como pela ocorrencla de dermatite amoniacal na maioris delas, embora não houvesse registro em prontuário.

Parece de suma importâncla a realização de higlene corporal satisfatória, evitando-se assim acumulo de sujidade, que propiciaria o desenvolvimento de microorganismos e instalação de processos infecciosos.

Em relação à higiene das mamadelras, 67,93\% das mães das crianças empregam métodos diversificados e considerados inadequados por não permittrez a correta limpeza das mesmas.

No que se refere à higiene na prepan ração dos alimentos, nota-se que apenss $15,10 \%$ das mães das crianças Informam executar açōes apropriadas quanto a esto cuidado.

Estes dados parecem importantes, considerando-se o significativo percentual de distúrblos nutritivos agudos, como causa de internaçōes e reinternaçōes e acentuada ocorrência de diarrélas como antecedentes mórbidos.

$\mathrm{Na}$ população estudada, constatou-se que $\mathbf{7 0 , 7 5 \%}$ do consumo de água é provenlente de reơe estatal, sendo que 
ROSA, M.S.O. e colaboradoras - Como proteger a criança de 0 a 24 meses contra a infeç̧o. Rev. Bras. Enf.; DF. 32 : 271-295, . 1979.

$29,25 \%$ apresentavam consumo de água de origem diversa.

Poder-se-ia questionar a validade dos resultados devido:

a) a impossibilidade de constatar a real qualidade da água (quantidade de cloro, limpeza da caixa d'água): e

b) ao alto nível de distúrbios nutritivos agudos encontrado na populaçāo estudada.

Veriffica-se que $58,50 \%$ dos grupos familiares não possuem rede de esgoto. Destes, $56,45 \%$ relatam boa localização da fossa e $43.55 \%$ localização inadequada.

Em relação ao destíno do lixo, observa-se que $58,48 \%$ da população estudada nāo é servida pela coleta pública, utilizando métodos pouco adequados para tal fim.

Embora a população não apresente instalaçōes sanitárias ideais, é aceitável o uso de outros melos, desde que haja uma boa orientação e supervisão sanitária. No entanto, parece que estas medidas não estão sendo aplicadas nesta população.

Em face destes dados pode-se classificar como deficiente o saneamento básico desta população.

Sabe-se que as condiçōes de saneamento de uma população interferem na instalação de processos infecciosos, sendo de vital importância que as deficiênclas existentes sejam sanadas.

\section{CONCLUSOES - RECOMENDAÇOES}

A análise e a discussão dos resultados obtidos nesta pesquisa bem como a bibliografia consultada, permitem algumas conclusões que serão expostas a seguir.

Após a exposição das conclusões serão apresentadas algumas recomendações que poderāo servir como linha de ação para a atuação do profissional de enfermagem.

\section{$5.1-$ Conclusões}

Através da análise e discussão dos dados verifica-se que há ocorrência significativa dos seguintes fatores:

a) baixo nível sócio-econômico-cultural;

b) nāo vacinação ou vacinação incompleta;

c) deficiente estado nutricional;

d) inadequada higiene ambiental.

Além destes podem ser citaclos: a condição de prematuridade, inadequada higlene corporal e a ocorrência de internaçōes anteriores por distúrbios nutritivos agudos e infecção de via aérea.

Pode-se concluir que os fatores acima relacionados promovem a debilidade do organismo, propiciando a instalação e o desenvolvimento do processo infeccioso na criança, o que é confirmado pela bibliogre ₹ia consultada.

Em 'ista disto, constata-se a necessidade da atuação do profissional de enfermagem a nível de prevenção primária. indispensável a preparação e motivaçāo deste profissional para realizar a prevençāo, através da educaçāo, na área materno-infantil. Esta educaçāo deve ser contínua e dinâmica, devendo ser reallzada junto às mães,-uma vez que estas, quando devidamente orientadas, contribuєm para clevar as níveis de saúde da criança e conseqüentemente da familia e da comunidade.

As ações de enfermagem a nivel de prevenção primária, junto à criança de zero a vinte e quatro meses, além de assegurar o crescimento e desenvolvimento da criança, contribuem para prevenção de fatores de risco (destes a infeç̧āo), possibilitam a identificação precoce de alterações na saúde da criança e concorrem para a reduçāo da taxa de morbidade e mortalidade infantil. 
ROSA, M.S.O. e colaboradoras - Como proteger a criança de 0 a 24 meses contra a infecção. Rev. Bras. Enf.; DF. 32 : 271-295, 1979.

\section{2 - Recomendações}

Em vista do exposto, sugere-se algumas recomendaçōes a nível de preverıção primária, dirigidas à população e aos profissionais da saúde:

\subsection{1 - Quanto à imunidade:}

- orientar a mulher em idade fértil da importâncla de um acompanhamento pré-natal o mais precocemente possível;

- capacitar o pessoal hospitalar, que entra em contato direto com o RN;

- realizar controles periódicos de saúde no pessoal de berçárlo;

- vigiar os cuidados de assepsia e de antissepsia, salientando a lavagem das mãos do pessoal que maneja com os RN;

- proporcionar maior supervisão aos cuidaoios prestados a prematuros.

\subsection{2. - Quanto à a:acinação:}

- informar as māes sobre a procura, o mais precocemente possivel, de um recurso da ccraunildade para obter çrteira de vacinação, e outras orientsçōes;

- manter o esquema vacinal em dia, sugerindo adoção do preconizado pelo Ministério da Saúcie do Brasil apresentado na referência bibliográfica. Quando não for possível seguir o esquema, estudar um novo calendário, respeitando o intervalo recomenáado entre as doses:

- orientar a populaçčo, individualmente ou por meio de campanhas, atravès cirs meios de comunicação, salientando a necessidade de vacinar a criança, esclarecendo o mecanismo de atuaçāo e época de aplicação da vacina;

- dar prioridade à vacina específica, na ocorrência de surto epiaêmico de alguma doença passivel de imunizaçāo;
- vacinar preventivamente com toxóide tetânico a gestante, utilizando 2 a 3 doses, a partir do quinto mês de gestação, visando proteção materna e de seu concepto.

\subsection{3 - Quanto à nutrição:}

- orientar sobre a necessidade de um bom estado nutricional materno, desde a concepção e suas interrelaçōes com o estado de nutriçāo da criança;

- detectar precocemente os fatores que possam gerar RN de baixo peso, estimulando o acompanhamento prénatal;

- salientar a importância de acompanhamento médico periódico para avaliação do estado de saúde da criança e a adequaçāo da dieta à capacidade digestiva e idade, principalmente, nos niveis sócio-econômicos-culturais mais baixos;

- orientar uma dieta equilibrada contendo lipidios, protídios, glicídios, água e sais minerais, estimulando a ingesta de alimentos naturais, visando desenvolver hábitos alimentares saudáveis.

\subsection{4 - Quanto ao aleitamento materno:}

- orientar a mãe sobre os benefícios da amamentação, salientando 0 aspecto emocional, ou nutritivo e de imunizaçāo, além das vantagens econôrnicas;

- estimular precomente, a população através de campanhas, conscientizando-a sobre a necessidade do aleitamento materno;

- ensinar a correta técnica de amamentaçāo: cuidados com mamas, ambiente calmo, esclarecendo relaçāo sucçāoproduçāo de leite, concorrendo para a segurança e tranqüilidade da puérpera; 
ROSA, M.S.O. e colaboradoras - Como proteger a criança de 0 a 24 meses contra a infecçá. Rev. Brad. Enf.; DF. 32 : 271-295, 1979.

- esclarecer sobre a duração mínima do aleitamento, em torno de 6 meses, informando sobre uma possível queda na produção do leite.

\subsection{5 - Quanto à higiene corporal e ambiental:}

- estimular o banho diário, tanto no inverno quanto no verão, usando sabão neutro e água corrente, se possível, enxugando a pele de modo a que fique rigorosamente seca, evitando correntes de ar durante e após o banho, completando com a exposição da criança ao sol ou luz;

- orientar uso de banheira individual para crianças até um ano, ou fazer higiente adequada após o uso no caso de ser utilizada por mais de uma criança;

- estimular a lavagem da cabeça o mais freqüentemente possível e/ou junto ao banho;

- orientar sobre a troca das fraldas quando sujas, molhadas ou após mamadas, realizando higiente perineal com água morna a cada troca;

- orientar sobre a higiene das fraldas com sabão e água, enxaguando adequadamente;
- higienizar as mamadeiras logo após 0 uso, com água, sabão neutro e escova apropriada. No momento de usá-la deverá passar por processo de fervura ou esterillização;

- estimular a higiente oral após as refeições, com escovação dos dentes;

- utilizar vestuário limpo, íntegro, cômodo, folgado, fácil de vestir e despir, sendo variável com a temperatura;

- formar hábitos, estimulando a regularidade nos horários de alimentação e sono, assim como, o costume de lavar as mãos antes das refeições e higienizar os dentes;

- orientar a população sobre a utilização adequada dos recursos de saneamento básico que o̊lspōe;

- orientar sobre o uso de água filtrada ou fervida para consumo da criança, principalmente, quando não proveniente de rede estatal;

- supervisionar a correta localização da fossa;

- orientar sobre o modo de desprezar os dejetos quando não há coleta pública;

- higienizar a casa diariamente, permitindo a ventilação e a entrada de luz.

\section{RAFERENCIAS BIBLIOGRAFICAS}

1. ALCANTARA, Pedro de \& MARCONDES, Eduardo. Pediatria Báefca. 4." ed. Såo Paulo, Sarvier, 1974, 2 v.

2. AMATO NETO, Vicente et alii. Imanitagáo. Săo Paulo, Sarvier, 1971.

3.

Vacinaçסes - Roteiro Prá-
tico e Culdados Gerais. Atwalida-
des Médicas. 8áo Paulo, 8(3): 19-
28, Jul. 1972,

4. AMATO NETO, Vicente. Reapareclmento da Varíla. Enfermagem em Novas Dimensāes. Sảo Paulo, 5(1): 63-4, jan./fev. 1979.

b. AVRRY, Gordon B. Neonatologla, Fisiologia e Cuidado do Recém-Nascido. Artes Médices, 1978.
6. BASTOS, N. C. de Brito. Controle des Doenças Transmissiveis. O programo da educação sanitária dos programas de imunizaçōes. Rev. Paulista de Hospitals. Såo Paulo, 24.8): 353-65, ago. 1876.

7. BIFR, Otto. Becterlologia e Imanologia. 17." ed. S8o Paulo, Melhoramentos, 1976.

8. BLANCR, Danilo et allt. Imunizaçio na Infancla. Rev. CASI. Porto Alegre, $37(U)$ : 70-82, 1976.

- BROLIO, Roberto. Programa de Profilaxia da Tuberculose. Rev. ia Divisão Nacional de Tuberculose. Rio de Janeiro, 21(84): 411-26, out./ dez., 1977. 
ROSA, M.8.O. e colaboradoras - Como proteger a criança de 0 a 24 meses contra a infeç̧̊̊. Rev. Bras. Ent.; DF. 32 : 271-295, 1979.

10. CARMTI, Clara de Rosa. Imunoglobulinas. Pediatria Básica. Såo Paulo, 43(5,6): 55-68, maio/jun. 1972.

11. CESARINO JUNIOR, A.F. Conceito de Higiene. Rev. da AMB. Rio de Janeiro, 13(6): 222-4, Jun. 1967.

12. COUTINHO, Ruy. Noçōes de Fisiologia da Nutrigăo. Rio de Janeiro, Cruzeiro, 1966.

13. CUNHA, Franklin M. \& CUNTA, Iole da. Aamamentaçāo uma Arte Esquecida. Rev. da AMRIGS. Porto Alegre, 20(3): 109-‘6, maio/junho 1976.

14. esmaraldo, Pancrácio de Almeida. Alimentação da Criança Sadia e Doente. Rev. Médica do Estado da Gnanabara. Rio de Janeiro, 40(2): 88-105, 1973.

15. FIORE, Francisco F. de. Normas Gerais da Alimentaçāo Infantil. Atualidades Médicas. São Paulo, (2) : 66-71, out. 1972.

16. FREITAS, riel G. de \& FIORI, Renato M. Septicemia no Recém-Nascido. Pesquisa Médica. Porto Alegre, 10(6): 349-64, 1974.

17. GESTEIRA, Raymundo Martagão. A Nova Puericultura. 1.* ed. São Paulo, Byk-Procienx, 1975.

18. GUYTON, Arthur C. Fisiologia Hama-

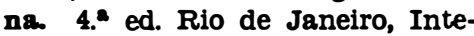
ramericana, 1976.

19. Tratado de Fisiologia Médica. 5." ed. Rio de Janeiro, Interamericana, 1977.

20. RAGGERTY, Robert J. Pediatria Preventiva e Higiene. In: Tratado de Pediatria. 6." ed., Barcelona, Salvat Editores, 1970, 1 v.

21. FENDERSON, Donald A. A Erradicacáo da Variola. A Saúde do Mundo. OMS, 22-27, fev./mar. 1977.

28. HOULI, Jacques \& GHEVENTER, Newton. Imunologia - Algums Noḉes Básicas. Joraal Brasileiro de Medicina. 65-78, Jun. 1973.

23. JOBDM, Luiz Fernando J. Deficiências Imunológicas. Rev. AMRIGS. Porto Alegre, 16(1): 43-9, mar. 1972.

24. KATIL, Aldonia C. et alif. Manual Bracico de Nutrigåa. Sảo Paulo, Instituto de Saúde, 1973.

28. Lo Salad del Nino en los Tróplces: Manual Practico para Personal Médico y Paramédico. Publicação Cientifica da OPS/ OMS (n. $\left.{ }^{\circ} 361\right), 2 .^{*}$ ed. Washington, 1978.
26. LAUPUS, William E. Higiene. In: Tratado de Pediatria. 6.* ed., Barcelona, Salvat Editores, 1970, 1 v.

27. LEAVELL, Hugh Rodman \& CLARK, E. Gurney. Medicina Preventiva. São Paulo, McGraw-Hill do Brasil, 1976.

28. LIMA, Azor José de. Alimentação do Primeiro Ano de Vida. Medicina de Hoje. 337-90, Jun. 1978.

29. MORLEY, David C. Seis Assassinos. A Saúde do Mundo. OMS. 4-7, fev./mar. 1977.

30. NOBREGA, Fernando José de \& TUDISCO, Eliette Salomon. Alimentação simplificada de baixo custo para crianças de 0-10 anos. Jornal de Pediatria. 43(6): 352'4, 1977.

31. OLIVEIRA, Suely de \& XAVIER, Dilma de A. Nutrição em Pediatria. Jornal Brasileiro de Medicina. jun. 1973.

32. PERNETTA, C sar. Distúrbios do Intercâmbio Nutritivo do Lactente. 3.* ed. Rio de Janeiro, Laemmert, 3." ed. Rio de Janeiro, Laemmert, 1954.

33. - Quinta Conferência Nacional de Saúde. Ministério da Saúde do Brasil. Brasilia, 1975.

34. - Riegos del Ambiente Hamano para la Salud. Publicaçãu científica da OPS/OMS (n.o 319). Washington, 1976.

35. SALOMON, João Bosco R. et alii. Infecçōes e desnutrição. Jornal de Pediatria. 41(13,14): 27-33, 1876.

36. SAIUM, M. J. L. Desnutrição proteicocalórica; uma breve revisão. Enfermagem em Novas Dimensóes. Săo Paulo. 2(4) : 209-14, 1976.

37. —undências na amamentagáa e seu impacto na saúde da criança. UNICEF, Brasil, 1978.

38. VHRONESI, Ricardi \& FOCACCIA, ROberto. Progressos em Vacinaçāes - Estado Atual das Imunizaçöes. Novas Vacinas e Perspectivas. Chnicas Pediátricas. 58-62, jul. 3978.

39. VDEGAS, Alfredo Reis. Higiene Dercária. In: Pediatria Básica. 4." ed. Såo Paulo, Sarvier, 1974, 1 v.

40. WAECHTHR, Eugênia H. \& BLANEs, Florence G. Enfermogem Pediktrica. 9." ed., Rio de Janeiro, Interamericana, 1979.

41. WANNMACHER, Clóvis M. D. \& DIAS, Renato Dutra. Bloquimica Fusdamental. 3." ed. Porto Alegre, Graphe, 1976. 